\section{The Oliver Memorial Fund for Blood Transfusion}

The Committee of the Oliver Memorial Fund for Blood Transfusion has given notice of its intention to make the sixteenth annual award of $£ 50$ and a plaquo rocording this to any British subject whoso original work or service in the field of blood transfusion is considored by the adjudicators to be an outstanding contribution to tho science, organization or donor aspect of this subject. The Committes welcomes communications directing its attention to suitable candidates and reserves tho right to divide the award in the event of a tio. In accordance with the rules the award this year will be restricted to lay men and women. Applications must be made by June 30 and should be sent to the honorary secrotary, Mrs. F. E. Bedborough, 105 New Park Avenue, Palmers Green, London, N.13.

\section{University News:}

Cambridge

THe following have been elected into fellowships at Churchill College: Title A from October 1, Dr. R. J. WattsTobin, of Trinity and Selwyn Colleges, College lecturer in mathematics; A. M. Walker, of Sidney Sussex College, University lecturer in mathematics; G. R. Allan, of Sidney Sussex College, College lecturer in mathematics. Title F (Overseas Fellowships), Dr. J. do V. Graaff, of St. John's College; Dr. F. T. McClure, chairman of the Research Center of the Applied Physics Laboratory of the Johns Hopkins Laboratory; Prof. P. Nozieres, professor of theoretical physics at the Faculté des Sciences, Paris; Dr. J. M. Ritchie, professor of pharmacology at the Albert Einstein College of Medicine, New York; Prof. W. D. Robertson, professor of metallurgy and solid-state seiences at Yale University; Dr. J. T. Wilson, of St. John's College, professor of physics and geology at the University of Toronto; Prof. B. Chance, director of the Johnson Research Foundation in the University of Pennsylvania; Dr. R. J. Cvetanovic, principal research officer and head of the Kinetics and Catalysis Section, National Rescarch Council of Canada.

London

Dr. Monica M. Colse, senior locturer in goography in the University of Keele, has been appointed to the chair of geography tenable at Bedford College. Dr. Anne Boloff-Chain, chief rosearch scientist in the Department of Biochemistry at the Istituto Superiore di Sanita, Rome, has boon appointed to the roadership in biochemistry tonable at tho Imperial Colloge of Scionce and Technology. Dr. B. M. Richards, a momber of tho scientific staff of the Medical Research Council Biophysics Research Unit in the Department of Biophysics at King's College, has boon appointed to the readership in biology at that College. Mr. I. M. Khabaza, lecturer at tho Computer Unit, has beon appointed to the readership in computing science tonable at Queen Mary College. Dr. J. R. Mallard, reador in medical physics at the Postgraduato Medical School of London, has been appointed to the roadorship in biophysics tonable at St. Thomas's Hospital Medical School.

\section{Sussex}

THE fourth annual report of the Univorsity of Sussex, covering the year ended July 31,1963 , records an increase in the acadomic faculty from 9 to 59, of whom 11 are professors and 29 lecturers (Pp. 36+xviii. London: H.M.S.O., 1963). Steps were taken to fill somo 50 more vacancies for 1963-64 and all were satisfactorily filled from a large number of applicants of high quality. The administrative faculty increased from 10 to 18 , and the addition of 40,000 volumes during the year brought the holdings of the Library at July 31 , 1963, to more than 70,000 ; of the accessions, 25,000 were purchased. Of the 442 students in the session, 221 were men and 221 were women; 26 were research students, 7 of whom were from overseas; 159 were registered for the B.Sc. course in the School of Physical Sciences, 82 for the B.A. in the School of Social Studies, 107 for tho B.A. in the School of English and American Studies, and 63 for the B.A. in the School of European Studies. There was an incroaso of moro than 50 per cont in applications for admission for 1963-64 compared with 1962-63. Of the 416 undergraduates, 310 wero accommodated in guest housos, 69 in lodgings, 11 at home and 26 in flats. The report also includes lists of spocial university lectures during the year and of publications by members of faculty.

\section{Announcements}

Mr. D. Broadbent, director of the Medical Research Council's Applied Psychology Research Unit, has boon awarded the 1964 Vernon Prize of the National Institute of Industrial Psychology. The Prize, founded by the late Dr. H. M. Vernon, of the Industrial Health Research Board, is awarded in alternate years to tho British investigator under forty-five years who, in the opinion of the Institute, has done most valuable research work in industrial psychology and physiology. Mr. Broadbent is prosident of the British Psychological Society.

The British Iron and Steel Federation has been awarded the 1964 Sir George Earle Trophy of the National Industrial Safety Committee of the Royal Society for the Prevention of Accidents. The award has been made to the Fedoration "in recognition of the important part it has played in the conspicuous progress in accident prevention within the steel industry which has been maintained since the setting up by the Federation in 1953 of permanent machinery for the centralized study of hazards and for the dissemination of knowledge of appropriate remedial action to all firms in the industry. Furthermore. its safety-educational material alone is of such a high standard that it has made a significant contribution to industrial safety in general".

TuE first international congress on "The Sea", organized by the University of Rennes and the Fédération Thermale: et Climatique de Bretagne, will be hold at Saint-Cast during May 31-June 6. Further information can bo obtained from the Fédération Thermale et Climatique do Bretagne, 6 rue La Fayetto, Rennes.

THE third International Congress of Polarography, arranged by the Polarographic Society, will bo held in the University of Southampton during July 19-25. Further information can be obtained from the organizing secretary, Dr. D. A. Pantony, Department of Metallurgy, Royal School of Mines, Prince Consort Road, London. S.W.7.

A JoInt meeting of tho Biochemical society and the Swodish Biochemical Society will be held in Stockholm during May 14-15. The meeting will include a colloquium on "Recent Advances in Soparation and Structural Analysis". Further information can bo obtainod from Dr. H. R. V. Arnstein, the Biochemical Socioty, 20 l'ark Crescent, London, W.1.

A ONE-YEAR postgraduate course in biochemical ongineoring, loading to a collego diploma and associato mombership of the Institution of Chemical Engineers, will be held at University College, London, as from October 1964. The course will cover engineering, biochomistry and microbiology, and is intended to train men for the biological industries, mainly those concerned with pharmacouticals, fonds and beverages. Further information can be obtained from Prof. M. B. Donald, Department of Chemical Engineering, University College, Gower Streot. London, W.C.1. 